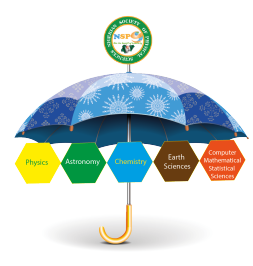

\title{
Evaluation of Aquifer Protective Capacity and Groundwater Potential in Part of Iju, Akure-North, Ondo State, Nigeria
}

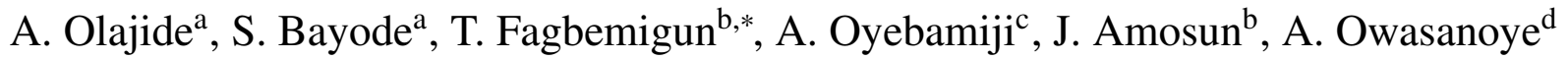 \\ ${ }^{a}$ Department of Applied Geophysics, Federal University of Technology Akure, Ondo State, Nigeria \\ ${ }^{b}$ Department of Geophysics, Federal University, Oye Ekiti, Ekiti State, Nigeria \\ ${ }^{c}$ Department of Geology, Federal University, Oye Ekiti, Ekiti State, Nigeria \\ ${ }^{d}$ Department of Physics, Federal University, Oye Ekiti, Ekiti State, Nigeria
}

\begin{abstract}
Groundwater potential and aquifer protective capacity of the overburden unit was evaluated in part of Iju, Akure North, Ondo State using integrated geophysical methods involving Very Low Frequency Electromagnetic (VLF-EM) profiling and Vertical Electrical Sounding (VES). Four major traverses were established of varying length extents. The VLF-EM measurements were taken along the four major profiles of $10 \mathrm{~m}$ station interval. Forty two (42) Vertical Electrical Soundings were also conducted with half electrode spacing varying between 1 and $100 \mathrm{~m}$ and interpretation was done using the partial curve matching techniques and computer aided iteration. Five subsurface geological units were identified from geoelectric sections, consisting of the top soil, lateritic, weathered, partly weathered and fresh basement layers consecutively. For the first layer, resistivity ranges between 23 and $323 \Omega m$ with values of thickness ranging between 0.5 and $2.2 \mathrm{~m}$. The resistivity and thickness of the second (lateritic) layer range from 132 to $430 \Omega m$ and 1.6 to $4 m$ respectively. The resistivity of the weathered layer ranges from 4 to $94 \Omega m$ and variable thickness between 10 and $24.4 \mathrm{~m}$. The fourth layer has a resistivity value range of 65 to $120 \Omega \mathrm{m}$ and thicknesses between 20 and $30 \mathrm{~m}$. The basement bedrock (fifth layer) has resistivity values between 770 and $820 \Omega \mathrm{m}$. The depth to bedrock ranges from 1.8 to $31 \mathrm{~m}$. The geophysical data and the basement aquifer delineated were then used to evaluate the hydrogeological setting and aquifer protective capacity of the study area. The observation from the results shows that close to $70 \%$ of the study area falls within the zones of low groundwater potential, $25 \%$ falls within medium potential zones while only $5 \%$ make up the high potential zones. $75 \%$ of the study area constituted the weak to poor protective capacity zones.
\end{abstract}

Keywords: Vertical Electrical Sounding, Very Low Frequency Electromagnetic, Groundwater Potential, Aquifer Protective Capacity

Article History :

Received: 02 January 2020

Received in revised form: 29 June 2020

Accepted for publication: 02 July 2020

Published: 01 August 2020

(C)2020 Journal of the Nigerian Society of Physical Sciences. All rights reserved. Communicated by: O. J. Abimbola

\section{Introduction}

The requirement for water is on the increase on a daily basis and its benefits for mankind are not farfetched. Water is a basic component of life and an essential food. Therefore, it is crucial to see, not only, to the sourcing for groundwater but also its

\footnotetext{
${ }^{*}$ Corresponding author tel. no:

Email address: tsfagbemigun@gmail.com (T. Fagbemigun )
}

protection against contamination from near surface materials. Protection of basement aquifers is just as important as its utilization but much more attention is given to its delineation than providing protective measures to ensure its safety from potential contaminants [1].

Contamination of hydro-geologic system has become a common occurrence within the metropolitan areas [2]. This is attributed to the availability of utilities such as: septic tanks, un- 
derground storage tanks of petroleum product, refuse dumpsite, shallow subsurface piping utilities and landfills. Most times, these facilities are not equipped with the appropriate liners to prevent percolation of contaminants into underlying aquifer particularly in areas where inhabitants rely mostly on groundwater. The absolute longitudinal conductance can be used in assessing overburden protective capacity in a region. This is on the ground that the earth medium goes about as a natural filter to permeating fluid. Measure of its protective capacity is ability to retard and filter permeating liquid [3], [4] depicted the protective capacity of an overburden overlying an aquifer as being corresponding to its hydraulic conductivity. High content of clay hinders smooth motion is by and large described by low resistivity esteems and low hydraulic conductivity and hence low longitudinal conductance.

Geophysical studies have proven to be one of the effective ways of evaluating an environment without interfering with the hydro geologic system [5]. Geophysical techniques have been used for the delineation of waste that are hazardous and groundwater contaminated areas and have been proven to be rapid and cost effective as emphasized by $[5,6,7]$. The observation derived from a geophysical exploration can be used to infer the conditions of subsurface at, and in the locality of an investigated area. Many researchers have used different geophysical methods to evaluate aquifer protective capacity and groundwater potential of an area using parameters such as the geoelectric parameters $[2,5,6,7]$.

This research therefore is aimed at evaluating the groundwater prospect and aquifer protective capacity of the overburden unit of the study area by carrying out the geophysical data acquisition using Vertical Electrical Sounding (VES) within the study area. Consequently, the geoelectric parameters will also be determined from the interpretation of Very Low Frequency Electromagnetic (VLF-EM) and VES data, along with vital properties such as the overburden thickness (depth to bedrock), bedrock subsurface structural features like faults/fractures which will aid the delineation of the basement aquifer associated with the study area. All these aforementioned findings are important for evaluating the hydrogeological settings of the study area.

\section{Study Area Description and Geology}

The area is situated within Iju, Akure North Local Government Area, Ondo State, Nigeria. It falls within Easting 0749749 to 0751021 , and Northing 0816800 to 0819200 (UTM) respectively of $31 \mathrm{~N}$ Minna datum (Fig. 1). The area extent is about $1 \mathrm{~km}^{2}$. The area has a low-lying topography. The elevation of the area varies between 360 and $390 \mathrm{~m}$ above mean sea level $(m s l)$. Sand and laterite are major constituents of the topsoil. Akure is situated in the south-western part of Nigeria underlain by Precambrian Basement Complex rocks (Fig. 2). The major rock units recognized in this area according to $[8,9,10]$

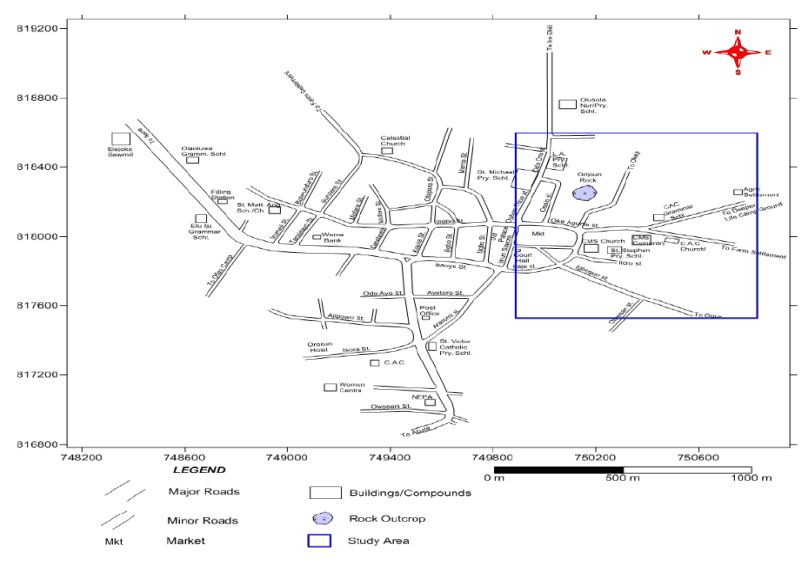

Figure 1. Map of Investigated Area [Modified After 17]

include; granite rocks, migmatite-gneiss complex, charnokitic meta-intrusive, quartzite serias and pellitic schist. These rocks occur as isolated and continuous hills and low-lying units that cover a wide area and rise to several hundred meters. The local lithologic units found in the study area include: granite rocks, migmatite-gneiss complex, charnokitic meta-intrusive.

\subsection{Hydrogeological Setting}

Akure, the Cosmopolitan capital city of Ondo State (comprising of several other smaller urban cities) in south-western part of Nigeria, is drained by River Ala, having numerous tributaries forming a typical dendritic system that flows in twofold directions: south-eastern and north-western [11].

Since the Akure area is characterized by underlying layers of basement rocks such as porphyritic granite, granite gneiss, charnockite and quartzite [12]; and thick layers of weathered and fractured regoliths exhibiting limited primary porosity, groundwater typically accumulates as a result of moderate to high secondary porosity from weathering and fractures existing in these crystalline geologic units $[13,14]$.

Furthermore, recharge of the groundwater systems in this city occurs primarily via infiltration from direct precipitation of about $1350 \mathrm{~mm}$ yearly [15] while secondary recharge depends on influent flow from River Ala and its network of small streams. Discharge of groundwater in Akure takes place in various forms including seepages, well or borehole abstraction, springs and outflows as surface water such as streams and rivers [16].

\section{Methodology}

VLF measurements were carried out along the four main Traverses; Traverse 1 is $570 \mathrm{~m}$ long, trending S-N direction, Traverse 2 is of length $550 \mathrm{~m}$, trending NE-SW direction, Traverse 3 is $490 \mathrm{~m}$ long, trending E-W direction, while traverse 4 is $520 \mathrm{~m}$ long and trends SE-NW directions respectively. Four 


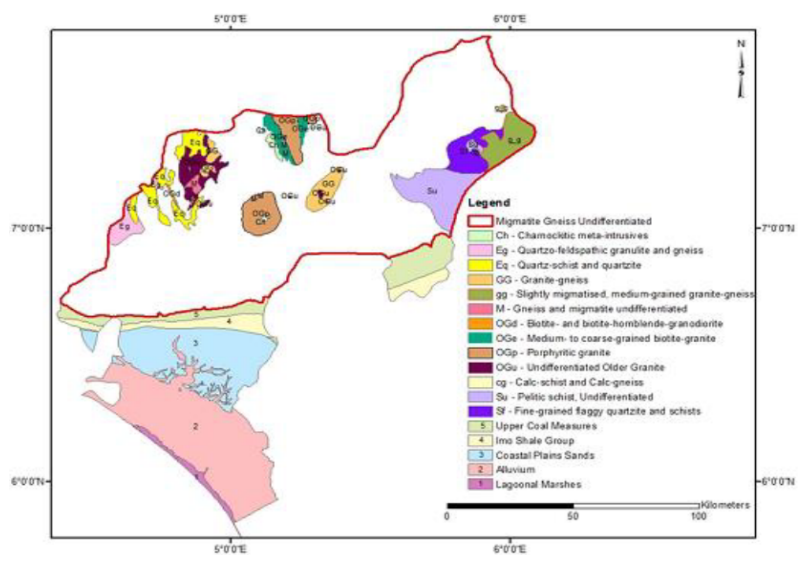

Figure 2. Geological Map of Ondo State (Digitized from NGSA Map, 1966)

VLF-EM Traverses were established along the existing roads within the study area and covered using ABEM WADI VLFEM. Raw real (quadrature) and filtered real measurement plots are presented as profiles and their 2-D image and the corresponding geoelectric section. The 2-D images show the difference of density of apparent current and conductivity variation with depth. With that kind of density of apparent current cross-section plots, it is promising to qualitatively differentiate between the conductive subsurface structure and low negative values are related to resistive zones. [18].

Several fairly conductive zones with relatively high current density were also revealed on the pseudosection with each zone of conductive matching with the positive peak amplitudes along the profile, which are indicative of fractures and faults where mapped; between distances $10-30 \mathrm{~m}, 90-130 \mathrm{~m}, 150-180 \mathrm{~m}$, $330-350 \mathrm{~m}$ along Traverse 1; $120-160 \mathrm{~m}$ and $450-470 \mathrm{~m}$ along Traverse 2; 20-50 $\mathrm{m}, 75-100 \mathrm{~m}$ and $130-170 \mathrm{~m}$ along Traverse 3 ; and 75-100 $\mathrm{m}, 120-140 \mathrm{~m}$ and $220-240 \mathrm{~m}$ along Traverse 4 respectively. However, such conductive zone could also result from external interference which might not necessarily be of subsurface impression. Hence, geoelectric sections are constructed along the VLF profiles where electric depth sounding has been conducted to have an enhanced understanding of the nature of subsurface geology. These conductive zones are important in groundwater delineation in a Basement Complex terrain $[19,20]$.

In the area of study, by and large, forty-two (42) VES were conducted. Traditional Schlumberger technique using AB/2 changing from 1 to $100 \mathrm{~m}$ was used. Vertical Electrical Sounding data were carried out in the available spaces and along existing roads and the established Traverses using Ohmega resistivity meter (Fig. 3). The maps generated from the interpreted result of the VES data include isoresistivity, topsoil isopach map, weathered layer, overburden thickness, groundwater potential and longitudinal conductance maps of the location.

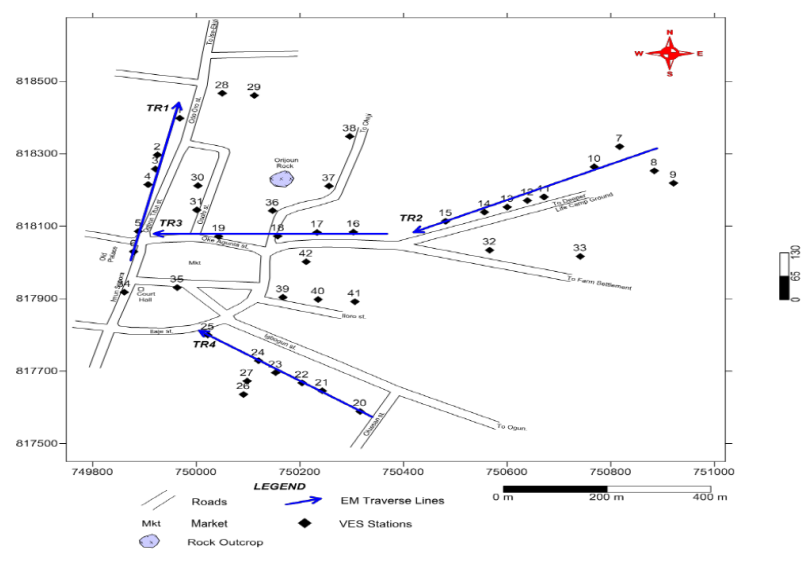

Figure 3. Data Acquisition map

Table 1. Showing the Frequencies and percentages of occurrence of Type Curves.

\begin{tabular}{lcc}
\hline Curve Type & Frequency & Percentage (\%) \\
\hline H & 29 & 69 \\
KH & 11 & 26 \\
HKH & 1 & 2.5 \\
HA & 1 & 2.5 \\
\hline
\end{tabular}

Parameter of Dar Zarrouk (longitudinal conductance) was obtained from first order geo-electric parameters. The total longitudinal conductance $\left(S_{T}\right)$ of the overburden unit at each VES station was acquired using equation (1) [21]:

$$
S_{T}=\sum_{i=1}^{n} \frac{h_{i}}{\rho_{i}}
$$

where $S_{T}=$ total longitudinal conductance of the overburden, $\rho_{i}=$ layer resistivity, $h_{i}=$ layer thickness and $n=$ number of layers and was used to classify the aquifer protective capacity of the study area.

\section{Results and Discussion}

\subsection{Vertical Electrical Sounding Type Curves}

The curve types obtained in the study area generally varies from $\mathrm{H}, \mathrm{KH}, \mathrm{HA}$ and $\mathrm{HKH}$. The most predominant curve type is H-type having a percentage frequency of $69 \%$, KH-type having $26 \%$, while $\mathrm{HKH} / \mathrm{HA}$ - types curve account for $2.5 \%$ each (Table 1). The type curves show that the lithologic sequences delineated varies from 3-5 layers.

\subsection{Geoelectric Sections}

Figures 4 - 7 show the corresponding geoelectric section for the VLF- EM along Traverses $1-4$. These layers: top soil, laterite, weathered, partly weathered, fractured basement and basement are revealed by geoelectric sections. 

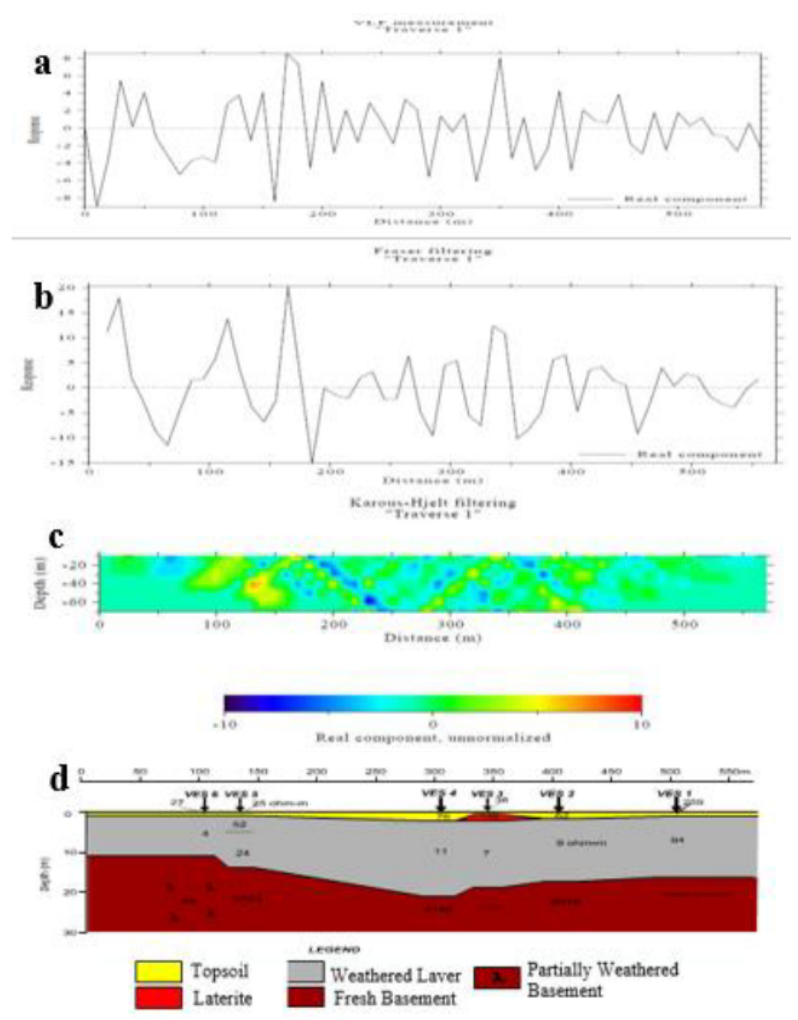

Figure 4. (a and b) VLF Profiles (c) 2-D Image and (d) Corresponding Geoelectric Section along Traverse 1.

First layer resistivity value ranges from $23-323 \Omega m$ along Traverse 1- 4, with thickness values ranges from $0.5-2.2 \mathrm{~m}$. Resistivity of low value $(<100 \Omega m)$ suggests clay characteristics, while resistivity of high value $(100-323 \Omega m)$ implies typical of sandy clay, lateritic clay and clayey- sand [22]. Generally, along the established traverses, topsoil is thin.

The second lithology is composed of lateritic layer with resistivity values ranging from $132-430 \Omega m$ along the four traverses (traverses 1 - 4). The thickness values vary from 1.6 $2.4 \mathrm{~m}$. The third lithologic unit is composed of weathered layer, with resistivity values ranges from $4-94 \Omega m$. The layer thickness generally varies from $10-24.4 \mathrm{~m}$. Resistivity values of the weathered layer showed clay to sandy clay and clayey sand lithologic units. Therefore, it can be concluded that the nature of the weathered layer is mostly responsible for the conductive zones revealed by the VLF-EM Profiles and 2-D images.

The fourth layer delineated beneath VES 6 along Traverse 1 shows partly weathered/fractured basement, with resistivity value of $65 \Omega m$. The fractured zone constitute little hydrological significance which is expected to contribute to the groundwater yield of the aquifer overlying it. The fifth layer is the fresh basement, with resistivity values ranging from $770-8203 \Omega m$. The depth-to-bedrock ranges from $2.2-30.8 \mathrm{~m}$. The aquifer units are the weathered layer and fractured zone constituting the major hydrogeological units within the area.

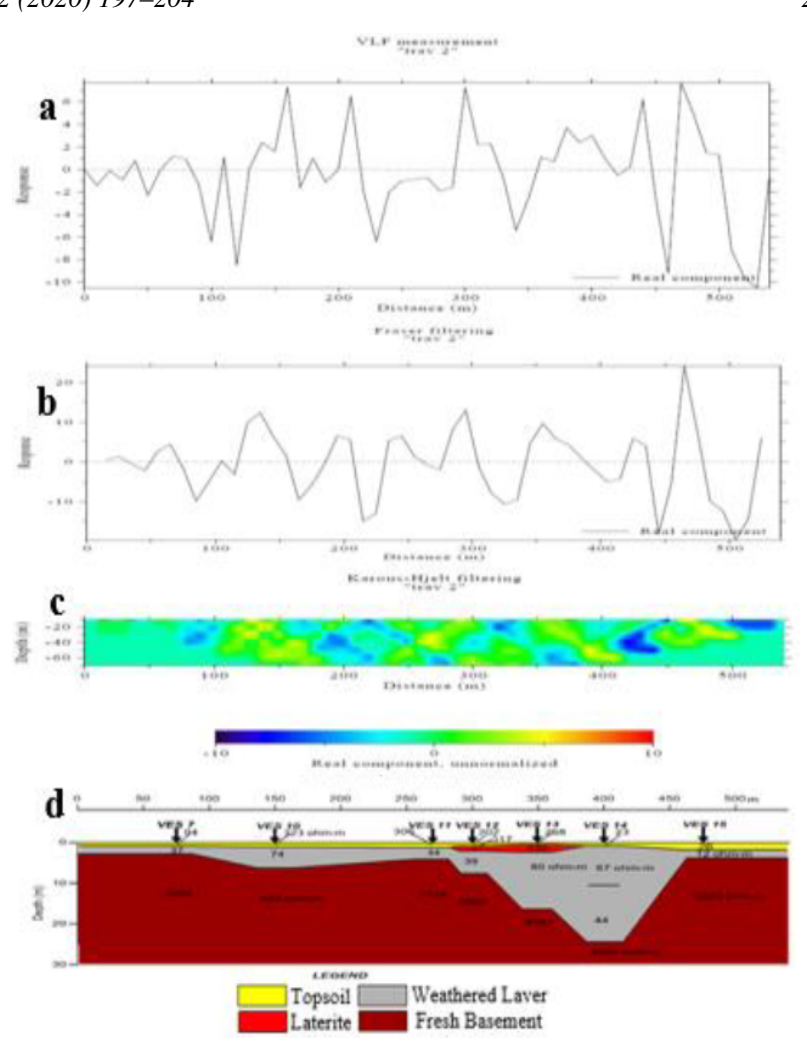

Figure 5. ( $a$ and b) VLF Profiles (c) 2-D Image and (d) Corresponding Geoelectric Section along Traverse 2.

Generally, the thickness of the overburden is thin $<10 \mathrm{~m}$ in major part of the investigated area (Figures 4 - 7). VES 1, 2, 3, $4,6,9,13$, and 22 with overburden thickness greater than $10 \mathrm{~m}$ may be considered favorable for siting of hand-dug wells but it should be expected that during dry season, such well may experience much or total dryness because the aquifer composition is clayey in nature. The overburden thickness beneath VES 14 and 20 is expected to contribute to the groundwater yield of the aquifer, with overburden thickness of $35 \mathrm{~m}$ and $33.6 \mathrm{~m}$ respectively. These can be considered for siting of shallow borehole (Table 2).

\subsection{Isoresistivity Map}

The topsoil Isoresistivity map was generated (Figure 8). The resistivity at the central part of the study area ranges from 20 $100 \Omega m$, which is depicted by clayey materials. The resistivity values of Northeastern, Northwestern and southern part of the location ranges between $100-340 \Omega m$, which shows that these area are covered by sandy clay, clayey sand and lateritic materials respectively.

\subsection{Resistivity Contour Map}

Contour map resistivity values of the weathered layer is shown in Figure 9. The weathered layer resistivity generally ranges from $4-260 \Omega m$. The low resistivity values of $4-$ 
Table 2. Showing the Interpreted Result of the Aquifer Layers and Thickness.

\begin{tabular}{|c|c|c|c|c|c|c|c|}
\hline VES NO & $\begin{array}{l}\text { Aquifer } \\
\text { Layer }\end{array}$ & $\begin{array}{c}\text { Aquifer } \\
\text { Thickness (m) }\end{array}$ & Remark & VES NO & $\begin{array}{c}\text { Aquifer } \\
\text { Layer }\end{array}$ & $\begin{array}{c}\text { Aquifer } \\
\text { Thickness (m) }\end{array}$ & Remark \\
\hline 1 & 2nd & 15.2 & Shallow well & 22 & 3rd & 10.7 & , \\
\hline 2 & 2nd & 15.8 & Shallow well & 23 & 2nd & 8.5 & Shallow well \\
\hline 3 & $3 \mathrm{rd}$ & 16 & Shallow well & 24 & 2nd & 6.5 &, \\
\hline 4 & 2nd & 18.8 & Shallow well & 25 & 2nd & 6.2 & , \\
\hline 5 & $3 \mathrm{rd}$ & 7.4 & Shallow well & 26 & 2nd & 9.9 & 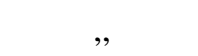 \\
\hline 6 & 2nd & 10 & Shallow well & 27 & $3 \mathrm{rd}$ & 5.7 & , \\
\hline 7 & 2nd & 2 & Shallow well & 28 & 2nd & 10 & , \\
\hline 8 & 2nd & 2.9 & Shallow well & 29 & 2nd & 3.3 & , \\
\hline 9 & $3 \mathrm{rd}$ & 10.9 & Shallow well & 30 & $3 \mathrm{rd}$ & 13.3 & , \\
\hline 10 & 2nd & 5.5 &, & 31 & $3 \mathrm{rd}$ and 4 th & 14.8 & , \\
\hline 11 & 2nd & 2.9 & , & 32 & 2nd & 4.7 & $"$ \\
\hline 12 & $3 \mathrm{rd}$ & 4.7 & , & 33 & 2nd & 3.5 & , \\
\hline 13 & 3rd & 13.4 &, & 34 & 2nd & 7.2 & , \\
\hline 14 & 2nd and 3rd & 23.5 & Shallow borehole & 35 & 2nd & 3.2 & , \\
\hline 15 & 2nd & 2.2 & Shallow well & 36 & 2nd & 6.5 & $"$ \\
\hline 16 & 2nd & 3.1 &, & 37 & 2nd & 3.4 & , \\
\hline 17 & 2nd & 4 & , & 38 & 2nd & 0.9 & , \\
\hline 18 & 2nd & 5 & , & 39 & 2nd & 3.1 & , \\
\hline 19 & 2nd & 6.9 &, & 40 & 2nd & 2.8 & , \\
\hline 20 & 2nd & 27 & Shallow borehole & 41 & 2nd & 3.4 & 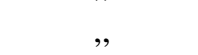 \\
\hline 21 & $3 \mathrm{rd}$ & 5.9 & Shallow well & 42 & 2nd & 3.6 & , \\
\hline
\end{tabular}

$60 \Omega m$ occupies the central part of the study area. The high resistivity values of $>60 \Omega m$ are found in the northwestern and southwestern part of the area. This is considered the main aquifer unit.

\subsection{Isopach Map}

The topsoil contour map shows that the thickness of the topsoil generally range from $0.4-2.2 \mathrm{~m}$ (Figure 10). The high thickness of $1.4-2.2 \mathrm{~m}$ is found in the central part of the area. The thickness of $0.4-1.2 \mathrm{~m}$ occupies the remaining part of the study area. The areas with thick topsoil also correlate to where thick overburdens were delineated within the area of study.

\subsection{Isopach Map of the Weathered Layer}

Isopach map of the weathered layer depicts the variation in the thickness over the study area Figure 11. It varies from $0.6-26 m$, thickest at Northeastern, Northwestern, southern and central eastern part of the study area, while it is thin in the central part with thickness range of $2-8 \mathrm{~m}$. The aquifer thickness is generally thin and less than $15 \mathrm{~m}$ except beneath VES 1, 2, 3, 4, 5, 6, 9,13, 14, 20 and 22 (Figure 11).

\subsection{Overburden Thickness Map}

The overburden is assumed to constitute all material above the fresh basement. The depth to the bedrock varies from 2.7-
$35 m$ (Figure 12). The map depicts that the southern part of the study area has the thickest overburden, followed by the Northwestern and east central part respectively. The remaining part of the area has thickness less than $15 \mathrm{~m}$. It is observed that the area with thick overburden correlates with thick weathered layer as such groundwater yield is expected to be high in such areas (Figure 12).

Generally, areas with thick overburden and low percentage of clay in which inter-granular flow is dominant are known to have high groundwater potential particularly in Basement Complex terrain [23].

\subsection{Groundwater Assessment}

The area of study where overburden thickness is $>25 \mathrm{~m}$ constitutes the main aquifer layer and low content of clay (between 100 and $300 \Omega m$ of average resistivity range) are considered as high potential of groundwater (Figure 13). Zones where overburden thickness is between 10 and $25 \mathrm{~m}$ and are of moderate content of clay (between 80 and $100 \Omega m$ of average resistivity range) are classified as areas of medium potential of groundwater [5, 24]. Zones where the thickness of aquifer is $<10 \mathrm{~m}$ and with average resistivity values $<80 \Omega \mathrm{m}$ are considered areas with low potential of groundwater rating [2].

Using the resistivity contour map of the weathered aquifer unit of the study area (Figure 9), it was seen that the clay substance of the overburden was high which educated the low po- 

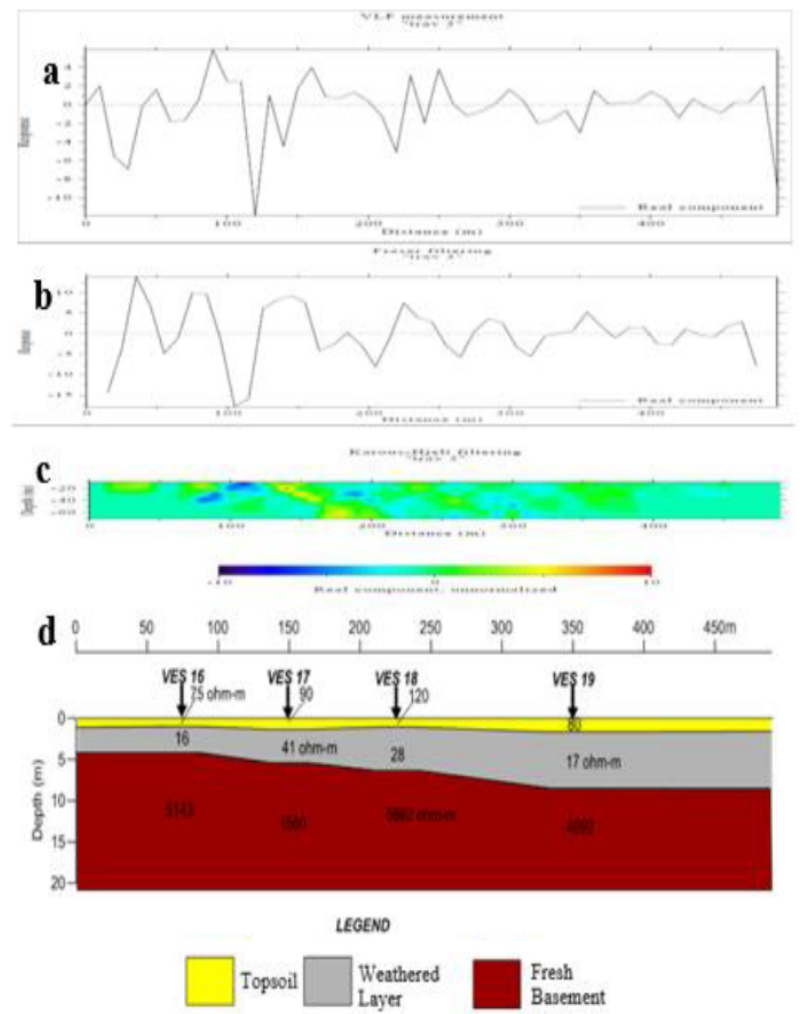

Figure 6. ( $a$ and b) VLF Profiles (c) 2-D Image and (d) Corresponding Geoelectric Section along Traverse 3.

tential of groundwater rating of the investigation zone inferable from low penetrability for the most part connected with clay.

It is observed that close to $70 \%$ of the area of study is contained in low potential of groundwater zone, $25 \%$ falls within medium potential zone while only $5 \%$ constitute the high potential zone (Figure 12).

\subsection{Evaluation of Aquifer Protective Capacity (APC)}

Figure 14 shows the longitudinal conductance of the investigation region. The high total longitudinal conductance unit of 2 - 2.5 mhos characterizes the extreme western part of the area of study (Figure 14). Using Table 3 to distinguish the protective ability of the study area into poor-week $<0.1-0.19$ mhos, moderate 0.2-0.69 mhos and good 0.7-4.49 mhos. Comparing the ST values with APC rating $[4,5]$ in Table 3 showed that the study area has $43 \%, 45 \%$ and $12 \%$ equivalent to "poor-weak", "moderate" and "good" APC, respectively. The low longitudinal conductance unit are found in major part of the area of study (Fig. 14). This shows that the aquifer unit in the investigated area is poorly protected from surface/near surface infiltration of pollutant. The protective capacity of western part is from moderate to good and it covered a small part of the area of study.

It is observed that the total longitudinal unit conductance value generally from 0.1 to 2.5 mhos range in the study area. The total longitudinal conductance units of 0 to 1 mhos are
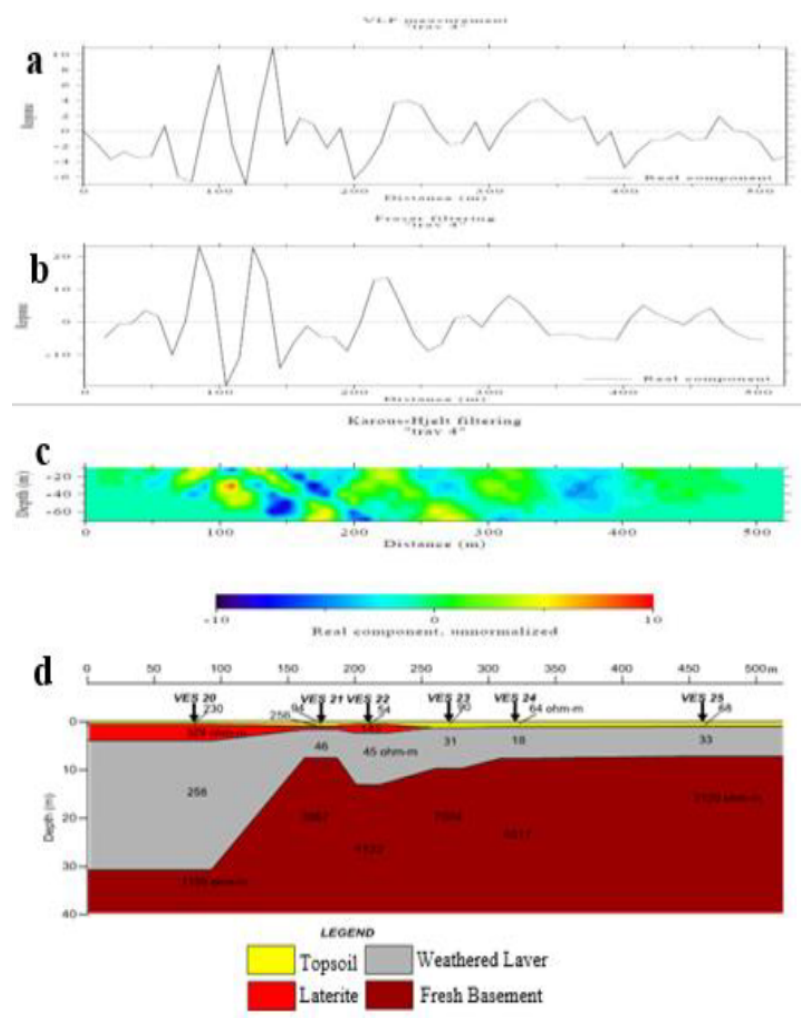

Figure 7. ( $a$ and b) VLF Profiles (c) 2-D Image and (d) Corresponding Geoelectric Section along Traverse 4.

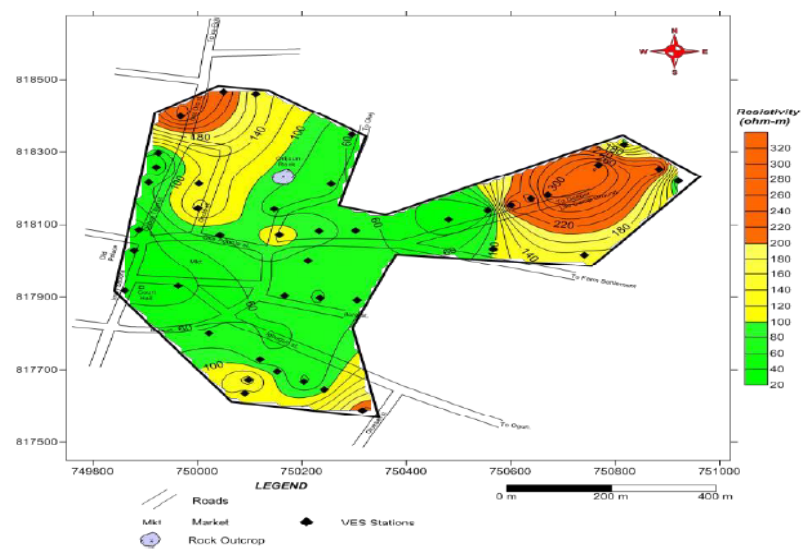

Figure 8. Topsoil Resistivity Contour Map.

found in the eastern, north and central parts of the study area, which are faintly protected. In the study area, the medium total longitudinal unit conductance values of 1 to 2 mhos are found in the western part and has high degree of protection compare to the parts of $>1$ mhos. It is observed that, $88 \%$ of the study area is poorly protected and it is in conformity with the reports of $[5,25]$ 
Table 3. Longitudinal conductance (mho) and aquifer protective capacity rating [4, 5].

\begin{tabular}{lccc}
\hline$S_{T}(m h o)$ & APC Rating & Percentage (\%) & VES Points \\
\hline$<0.1-0.19$ & Poor - Weak & 43 & $1,7,8,9,10,11,12,13,17,20,21,28,29,32,33,38.39,40$ \\
$0.2-0.69$ & Moderate & 45 & $5,14,15,16,18,19,22,23,24,25,26,27,30,31,35,36,37,41,42$ \\
$0.7-4.49$ & Good & 12 & $2,3,4,6,34$ \\
$5-10$ & Very Good & - & \\
$>10$ & Excellent & - & \\
\hline
\end{tabular}

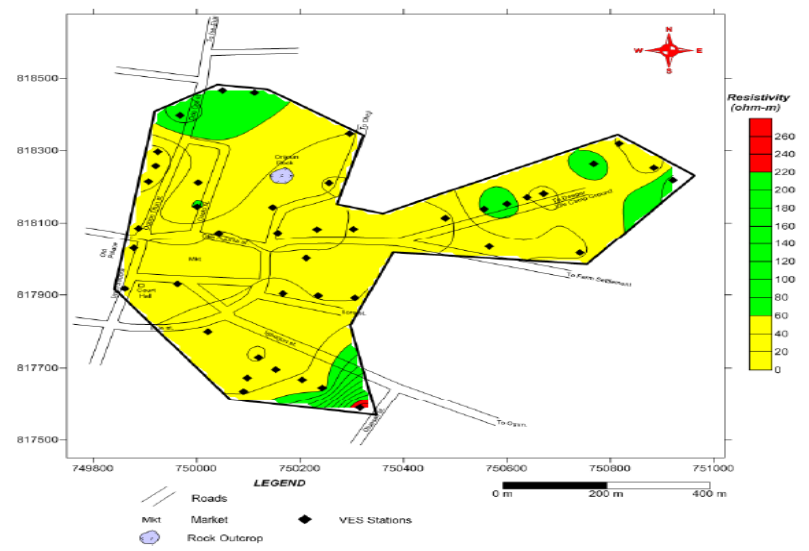

Figure 9. Weathered Layer Resistivity Contour Map.

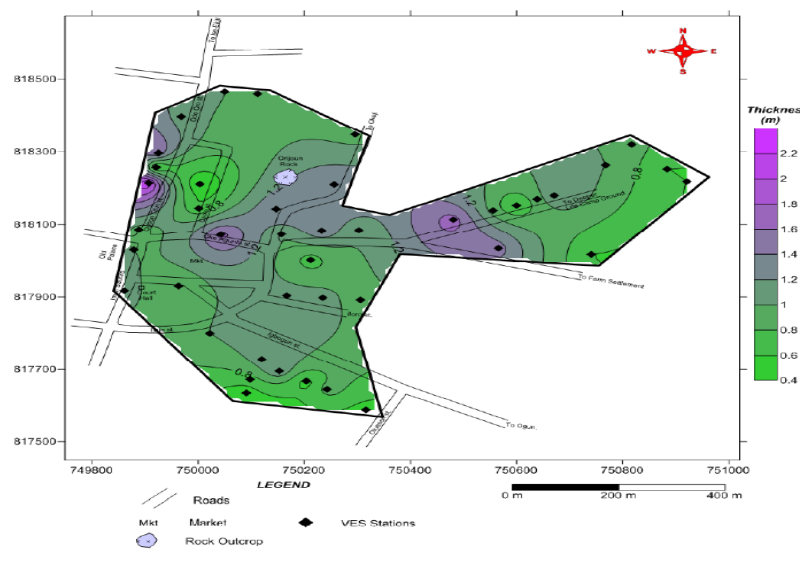

Figure 10. Isopach Map of Topsoil.

\section{Conclusion}

Generally, the VLF-EM and VES results generated have been used to assess the potential of groundwater and aquifer vulnerability within the area of study. The larger part of the area of study (about $70 \%$ ) is situated within low groundwater potential zones, $25 \%$ falls within medium potential zones while only $5 \%$ constitute the high potential zones. Also the aquifer protective capacity assessment shows that $<15 \%$ of the study area aquifer have moderate to good protective capacity, while the weak to poor protective capacity occupied about $75 \%$ of the study are. Thus, the weakly and poorly protected part of the area of study is liable to contamination from near-surface

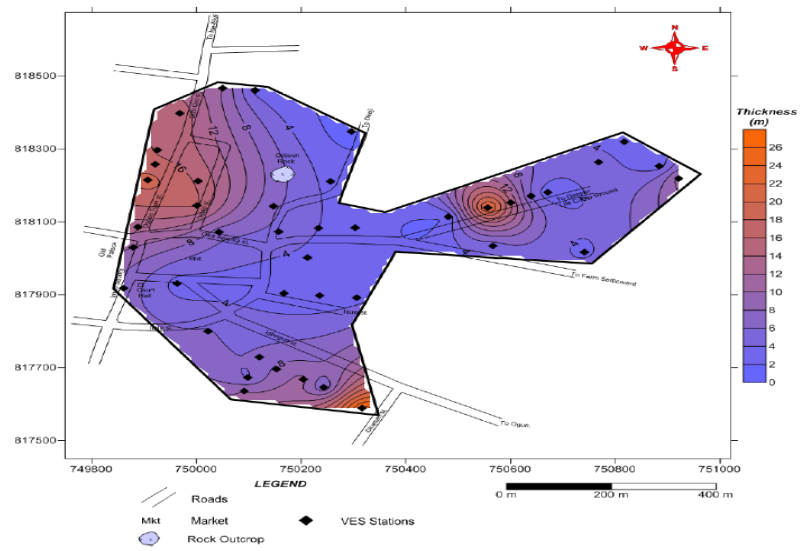

Figure 11. Isopach Map of the Weathered Layer.

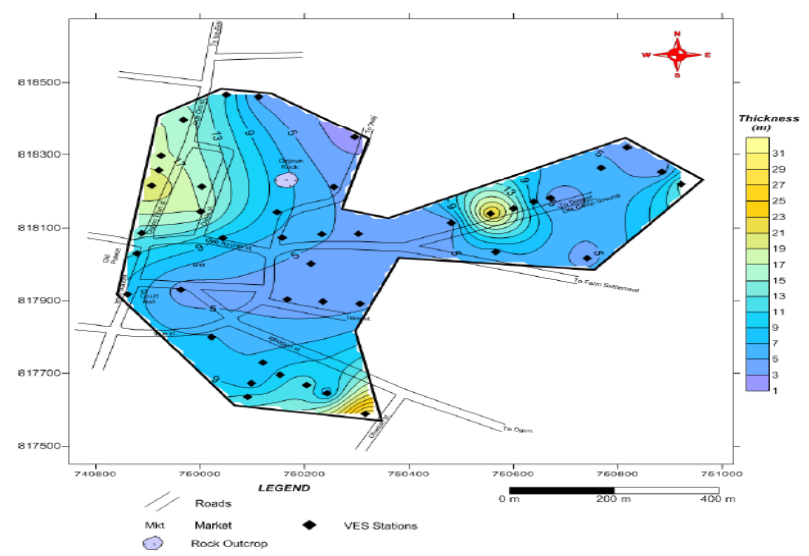

Figure 12. Overburden Thickness Map.

materials.

This study's result is a reliable provision of background data for elaborate planning of the development and sustainability of groundwater resources within the area of study and hence, it is recommended that future development of groundwater in the study area should be limited to the areas with high and medium groundwater potential. Also, consideration should be given to areas with shallow water table as highlighted in the study for engineering and building construction purposes. 


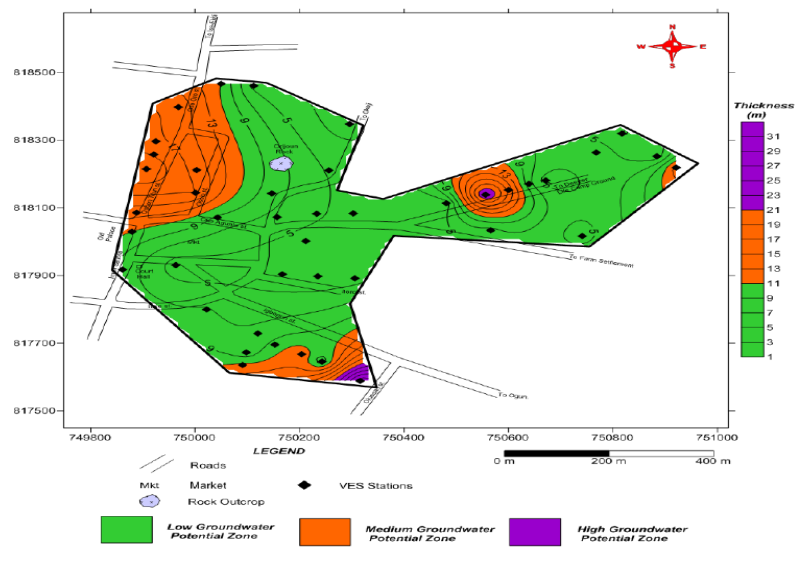

Figure 13. Groundwater Potential Map.

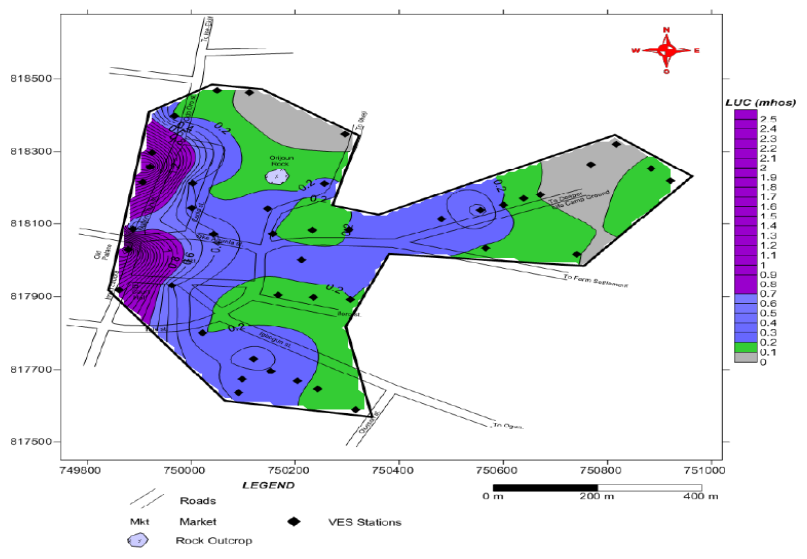

Figure 14. Map of Total Longitudinal Unit Conductance.

\section{Acknowledgments}

We thank the referees for the positive enlightening comments and suggestions, which have greatly helped us in making improvements to this paper.

\section{References}

[1] C. A. Sullivan, J. R. Meigh \& A. M. Giacomello, "The water poverty index: development and application at the community scale" In Natural resources forum 27 (2003) 189.

[2] M. I. Oladapo, O. J. Akintorinwa, "Hydro Geophysical Study of Ogbese Southwestern, Nigeria" Global J Pure and Applied Sci. 13 (2007) 55.

[3] J. F. Olorunfemi \& C. O. Odita, "Land use and solid waste generation in Ilorin, Kwara State, Nigeria” Environmentalist 18 (1998) 67.

[4] Henrient, "Direct Application of Dar Zarrok Parameter In Groundwater Survey", Geophysical Prospect 24 (1976).

[5] M. I. Oladapo, M. Z. Mohammed, O. O. Adeoye, B. A. Adetola, "Geoelectrical Investigation of the Housing Corporation Estate Ijapo Akure, Southwestern Nigeria" Journ. Min Geol 40 (2004) 41.

[6] G. O. Omosuyi, "Geoelectric Assessment of Groundwater Prospect and Vulnerability of Overburden Aquifer at Idanre South Western Part of Nigeria" Ozean Journ. Appl. Sci. 3 (2010) 19.
[7] M. F. Walter, A. C. Braga, J. C. Dourado, "Resistivity (DC) Method Applied to Aquifer Protection studies" Rbgf 24 (2006) 573.

[8] M. A. Rahaman \& O. Ocan, "On relationship in the Precambrian migmatite-gneiss of Nigeria" Journal of Mining and Geology 15 (1978) 23.

[9] A. N. Dempster, "Geological Map of Akure on 1: 250000, Sheet 61", Geological Survey of Nigeria (1966).

[10] V. O. Olarewanju, "Geochemistry of charnockitic and granitic rocks of the basement around Ado-Ekiti - Akure, Southwestern Nigeria" PhD Thesis, University of London (1981).

[11] Y. A. Asiwaju-Bello, F. O. Olabode, O. A. Duvbiama, O. I. Iyamu, A. A. Adeyemo, \& M. T. Onigbinde, "Hydrochemical evaluation of groundwater in Akure Area, South-western Nigeria, for irrigation purpose" Eur. Int. Journ. Sci. Technol. 2 (2013) 235.

[12] A. Y. B. Anifowose, "Stabilization of lateritic soils as a raw material for building blocks" Bull. Eng. Geol. Environ. 58 (2000) 151.

[13] O. O. Aladejana, A. Y. B. Anifowose, \& B. J. Fagbohun, "Testing the ability of an empirical hydrological model to verify a knowledgebased groundwater potential zone mapping methodology" Model Earth Syst Environ 2 (2016) 1.

[14] O. F. Olabode, "Potential groundwater recharge sites mapping in a typical basement terrain: a GIS methodology approach" Journ Geovis Spat Anal 3 (2019) 5 .

[15] Y. A. Asiwaju-Bello, O. F. Olabode \& M. T. Ogunsuyi, "Pollution potential and causative hydrogeochemical processes in unconfined aquifer systems in a typical urban setting: emphasis on recharge and discharge areas" Applied Water Science 10 (2020) 52.

[16] J. O. Owoseni, E. H. Tamarautobou \& Y. A. Asiwaju-Bello, "Application of sequential analysis and geographic information systems for hydrochemical evolution survey, Shagari Environ, Southwestern Nigeria" Am Int Journ Contem Res 5 (2013) 38.

[17] A. T. Adediji \& M. O. Ajewole, "Vertical Profile of Radio Refractivity Gradient inAkure South-West Nigeria" Progress in electromagnetics research 4 (2008) 157.

[18] S. Benson, C. R. Jones, "The combined EMT/VES Geophysical method of siting borehole" (1998) 54

[19] G. O. Omosuyi, A. Adeyemo \& A. O. Adegoke, "Investigation of groundwater prospect using electromagnetic and geoelectric sounding at Afunbiowo, near Akure, Southwestern Nigeria" Pacific Journ Sci Technol 8 (2007) 172.

[20] K. A. N. Adiat, G. M. Olayanju, G. O. Omosuyi \& B. D. Ako, "Electromagnetic profiling and electrical resistivity soundings in groundwater investigation of a typical Basement Complex-a case study of Oda Town Southwestern Nigeria" Ozean Journal of Applied Sciences 2 (2009) 333.

[21] E. T. Okhue, \& M. O. Olorunfemi, "Electrical resistivity investigation of a Typical Basement Complex area-the Obafemi Awolowo University Campus case study" Journ Min Geol 27 (1991) 66.

[22] C. I. Adenika, E. A. Ariyibi, M. O. Awoyemi, A. S. Adebayo, O. A. Dasho, \& E. O. Olagunju, "Application of geophysical approach to highway pavement failure: a case study from basement complex terrain southwestern Nigeria" Geo-Engineering 9 (2018) 1.

[23] A. A. R. Zohdy, G. P. Eaton, \& D. R. Mabey, “Application of surface geophysics to groundwater investigations" United State Geophysical Survey, Washington (1974).

[24] M. O. Olorunfemi \& E. T. Okhue, "Hydrogeological and Geologic significance of a geoelectric survey at Ile-Ife" Nigeria Journal of Mining and Geosciences Society 28 (1992) 221.

[25] M. I. Oladapo \& F. I. Afuda, "Hydrogeophysical Study of Parts of Charnockiteterrain of Akure Southwestern Nigeria" Global Journal of Pure and Applied Sciences, 23 (2017) 107. 